\title{
PERTUMBUHAN DAN PRODUKTIVITAS JAMUR TIRAM PUTIH (Pleurotus ostreatus) PADA KOMPOSISI MEDIA TANAM SENGON DAN JERAMI
}

\section{GROWTH AND PRODUCTIVITY OF OYSTER MUSHROOM (Pleurotus ostreatus) IN MEDIA COMPOSITION OF SENGON AND STRAW PLANT}

\author{
Henni Elfandari ${ }^{1}$, Yusanto ${ }^{1}$ dan Septiana ${ }^{1}$ \\ ${ }^{1}$ Program Studi Hortikultura, Politeknik Negeri Lampung, Bandar Lampung; Indonesia \\ *Email: elfandarihenni@polinela.ac.id
}

*Corresponding Author, Diterima: 6 Apr. 2021, Direvisi: 27 Apr. 2021, Disetujui: 17 Mei 2021

\begin{abstract}
Oyster mushrooms are one of the most popular consumption mushrooms because they have a delicious taste and high nutritional value. Oyster mushrooms can be cultivated in a medium (baglog) derived from rotten wood dust or lignin and wrapped in plastic and sterilized. The raw material for sawdust is increasingly difficult to obtain because of the reduced use of wood which causes the price of sawdust to be more expensive and the cost of producing mushrooms to be more expensive. So that we need an alternative lignocellulosic waste as a medium for fungal growth, one of which is straw. This study used a single treatment in a randomized block design (RBD) with four replications. The combination treatment of sengon and straw media consisted of 8 levels. $P_{0}=$ Sawdust 100\%; $P_{1}=$ Sawdust $90 \%+$ Straw 10\%; $P_{2}=$ Sawdust $80 \%+$ Straw 20\%; $P_{3}=$ Sawdust 70\% + Straw 30\%; $P_{4}=$ Sawdust 60\% + Straw 40\%; $P_{5}=$ Sawdust 50\% + Straw 50\%; $P_{6}=$ Sawdust 40\% + Straw 60\%; $P_{7}=$ Sawdust 30\% + Straw 70\%. The experiment was repeated four times. The results showed that oyster mushrooms grown on 100\% sengon wood powder media showed the best growth and productivity compared to other treatments.
\end{abstract}

Keywords: Oyster mushroom, sawdust, straw, sengon

\begin{abstract}
ABSTRAK
Jamur tiram merupakan jamur konsumsi yang disukai oleh masyarakat karena memiliki rasa yang enak dan nilai gizi yang tinggi. Jamur tiram dapat dibudidayakan dalam media (Baglog) yang berasal dari serbuk kayu atau bahan lignin yang telah lapuk dan dibungkus plastik dan disterilkan. Bahan baku serbuk kayu semakin sulit diperoleh karena berkurangnya pemanfaatan kayu, yang menyebabkan harga serbuk kayu semakin tinggi dan biaya produksi jamur akan meningkat. Oleh karena itu diperlukan alternatif limbah lignoselulosa yang diperlukan sebagai media untuk pertumbuhan jamur, salah satunya adalah jerami. Penelitian ini menggunakan perlakuan tunggal dalam rancangan acak kelompok (RAK) dengan empat ulangan. Perlakuan kombinasi media sengon dan jerami terdiri dari 8 taraf. $\mathrm{P}_{0}=$ Serbuk kayu sengon $100 \% ; \mathrm{P}_{1}=$ Serbuk kayu sengon $90 \%+$ Jerami $10 \% ; \mathrm{P}_{2}=$ Serbuk kayu sengon $80 \%+$ Jerami $20 \% ; \mathrm{P}_{3}=$ Serbuk kayu sengon $70 \%+$ Jerami $30 \% ; \mathrm{P}_{4}=$ Serbuk kayu sengon $60 \%+$ Jerami $40 \% ; \mathrm{P}_{5}=$ Serbuk kayu sengon 50\% + Jerami 50\%; $\mathrm{P}_{6}=$ Serbuk kayu sengon $40 \%+$ Jerami $60 \% ; \mathrm{P}_{7}=$ Serbuk kayu sengon $30 \%$ + Jerami $70 \%$. Percobaan diulang sebanyak empat kali. Hasil penelitian diketahui bahwa jamur yang ditanam pada media $100 \%$ serbuk kayu sengon menunjukkan pertumbuhan dan produktivitas terbaik dibandingkan dengan perlakuan lainnya.
\end{abstract}

Kata kunci : Jamur tiram, jerami, sengon, serbuk kayu. 


\section{PENDAHULUAN}

Jamur merupakan tumbuhan yang banyak dan mudah dijumpai di alam, seperti di hutan atau kebun. Jamur banyak dijumpai terutama pada musim hujan. Jamur tiram putih (Pleuroptus ostreatus) merupakan salah satu jenis jamur kayu. Jamur banyak dimanfaatkan sebagai sayuran dan obat-obatan karena rasa yang lezat dan berkhasiat bagi kesehatan (Cahyana, 2006).

Dundar et al. (2008) menyatakan bahwa kandungan nutrisi dalam 100 gram berat kering jamur tiram putih terdiri dari protein 17,12 , lemak 2,60 g, karbohidrat 37,87 g, energi 243,66 g, serat 30,25 g, dan abu 4,8 g. Budidaya jamur tiram putih (Pleurotus ostreatus) merupakan salah satu usaha agribisnis yang memiliki peluang bisnis cukup besar karena dalam 10 tahun terakhir nilaiekonomis jamur tiram putih terus meningkat (Syammahfuz dalam Setiagama, 2014; Amelia dkk., 2017).

Budidaya jamur tiram memerlukan media tumbuh yang mempunyai komposisi formulasi tertentu, diantaranya serbuk kayu gergaji, bekatul, kapur, dan gips. Komposisi masing-masing media berbeda, hal ini sangat menentukan keberhasilan tumbuh dan besarnya produksi jamur (Widyastuti dan Istini, 2004).

Jamur umumnya dibudidayakan dalam media Baglog. Secara umum, bubuk yang digunakan berasal dari kayu sengon yang memiliki kandungan selulosa $49,90 \%$, hemiselulosa $24,59 \%$, dan $26,80 \%$ lignin (Rahma dan Purnomo, 2016). Bahan baku serbuk kayu semakin sulit diperoleh karena berkurangnya pemanfaatan kayu, yang menyebabkan harga serbuk kayu semakin tinggi dan biaya produksi jamur akan meningkat. Oleh karena itu diperlukan alternatif limbah lignoselulosa yang diperlukan sebagai media untuk pertumbuhan jamur, salah satunya adalah jerami.

\section{BAHAN DAN METODE}

\section{Waktu dan Tempat}

Penelitian ini dilaksanakan di Kubung Jamur, Program Studi Hortikultura, Jurusan Budidaya Tanaman Pangan, Politeknik Negeri Lampung dari Juni 2020 sampai dengan November 2020.

\section{Alat dan Bahan}

Bahan yang digunakan adalah sengon, jerami, bekatul (dedak), kapur $\left(\mathrm{CaCO}_{3}\right)$, glukosa, kantong plastik, karet, kapas. Adapun alat yang digunakan adalah cangkul, sekop, filler, botol, boiler, gerobak dorong, sendok bibit, centong, blower, selang, dan alat pasteurisasi, cincin plastic, erlenmeyer, timbangan analitik.

Rancangan disusun dan dilaksanakan dengan menggunakan Rancangan Acak Kelmpok (RAK) dengan perlakuan komposisi media tanam yang terdiri dari 8 taraf, yaitu :

$\mathrm{P}_{0}=$ Serbuk kayu sengon $100 \%$

$\mathrm{P}_{1}=$ Serbuk kayu sengon90\% + Jerami 10\%

$\mathrm{P}_{2}=$ Serbuk kayu sengon80\% + Jerami 20\%

$\mathrm{P}_{3}=$ Serbuk kayu sengon $70 \%+$ Jerami 30\%

$\mathrm{P}_{4}=$ Serbuk kayu sengon $60 \%+$ Jerami $40 \%$

$\mathrm{P}_{5}=$ Serbuk kayu sengon50\% + Jerami 50\%

$\mathrm{P}_{6}=$ Serbuk kayu sengon $40 \%+$ Jerami $60 \%$

$\mathrm{P}_{7}=$ Serbuk kayu sengon30\% + Jerami $70 \%$

Percobaan diulang sebanyak empat kali.

Pengamatan dilakukan pada parameter hari munculnya miselium, hari munculnya tubuh buah, panjang tangkai buah, jumlah tubuh buah, diameter tudung buah dan bobot basah tubuh buah jamur. Data 
yang diperoleh akan diuji $\mathrm{F}$ (analisis ragam), dan dilanjutkan dengan uji pemisahan nilai tengah dengan Uji BNT pada taraf $\alpha 5 \%$.

\section{HASIL DAN PEMBAHASAN}

Berdasarkan pengamatan selama penelitian didapatkan data sebagaimana pada Tabel 1. Hasil analisis statistik menunjukkan bahwa perlakuan $\mathrm{P}_{0}$ memiliki waktu tercepat pada pertumbuhan miselium yaitu miselium muncul pada 3 hari setelah masa inkubasi (hsi) jika dibandingkan dengan perlakuan lain.

Pertumbuhan miselium yang baik disebabkan oleh adanya media tumbuh jamur yang terdekomposisi secara cepat dan merata, sehingga unsur-unsur hara yang terdapat pada media tumbuh. Serbuk kayu sengon selain memiliki kandungan lignin, juga memliki kandungan selulosa dan hemiselulosa. Kandungan selulosa pada serbuk kayu sengon sebesar 49,40\% dan kandungan hemiselulosa sebesar 24,59\%. Fungsi selulosa adalah memperkuat dinding sel tanaman sedangkan di dalam pencernaan, berperan sebagai pengikat air, namun jenis serat ini tidak larut dalam air. Hemiselulosa berfungsi memperkuat dinding sel tanaman dan sebagai cadangan makanan bagitanaman. Sifatnya sama dengan selulosa, yaitu mampu berikatan dengan air (Sunanto, 2000).

Pengaruh waktu pertumbuhan miselium selaras dengan hari munculnya badan buah. Pada perlakuan $\mathrm{P}_{0}$ memiliki waktu tercepat dalam pertumbuhan badan buah yakni 28,3 hsi. Hal ini sejalan dengan pendapat Sumiati (2005), bahwa jika penyebaran miselium cepat maka akan semakin cepat pula dalam pembentukan badan buah.

Panjang tangkai buah jamur terpanjang terdapat pada perlakuan $\mathrm{P}_{0}$ dan $\mathrm{P}_{1}$ sebesar $4,9 \mathrm{~cm}$. Media tanam dengan bahan-bahan yang cepat terdekomposisi menjadi media yang ideal bagi pertumbuhan jamur. Bahan organik yang mengandung selulosa dan lignin dalam jumlah yang besar akan mendukung pertumbuhan dan perkembangan tubuh jamur (Stevani, 2011).

Perlakuan media tanam 100\% serbuk kayu sengon $\left(\mathrm{P}_{0}\right)$ menghasilkan jumlah tubuh buah terbanyak yaitu 4,9 tubuh buah jamur. Hal ini disebabkan karena badan buah yang terbentuk biasanya tergantung pada banyaknya primordia yang tumbuh. Jika primordianya

Tabel 1. Hasil Pengamatan Pertumbuhan dan Hasil Jamur Tiram pada Berbagai Komposisi Medai Tanam

\begin{tabular}{|c|c|c|c|c|c|c|}
\hline Perlakuan & $\begin{array}{l}\text { Hari munculnya } \\
\text { miselium (hsi) }\end{array}$ & $\begin{array}{l}\text { Hari munculnya } \\
\text { tubuh buah (hsi) }\end{array}$ & $\begin{array}{c}\text { Panjang tangkai } \\
\text { buah }(\mathrm{cm})\end{array}$ & $\begin{array}{c}\text { Jumlah } \\
\text { tubuh buah }\end{array}$ & $\begin{array}{l}\text { Diameter tudung } \\
\text { buah }(\mathrm{cm})\end{array}$ & $\begin{array}{l}\text { Bobot basah } \\
\text { tubuh buah }(\mathrm{g})\end{array}$ \\
\hline P0 & $3,0 \quad \mathrm{~d}$ & $28,3 \quad \mathrm{c}$ & $4,9 \quad \mathrm{a}$ & 4,9 a & $12,0 \quad a b$ & $9,1 \quad \mathrm{a}$ \\
\hline $\mathrm{P} 1$ & 5,0 & 32,0 & 4,9 & 3,8 bc & $11,9 \mathrm{ab}$ & 4,2 \\
\hline $\mathrm{P} 2$ & 5,3 & 33,3 & 4,8 & 4,4 abc & $11,7 \mathrm{ab}$ & 3,3 \\
\hline P3 & 6,7 & 35,3 & 3,8 & 3,9 abc & $10,7 \quad b$ & 3,0 \\
\hline P4 & 7,0 & 34,0 & 4,6 & $3,3 \mathrm{c}$ & $12,5 \mathrm{ab}$ & 3,2 \\
\hline P5 & 9,7 & 34,6 & 4,5 & $4,8 \mathrm{ab}$ & 14,7 a & 2,0 \\
\hline P6 & 0,0 & 0,0 & 0,0 & $0,0 \quad \mathrm{~d}$ & 0,0 & 0,0 \\
\hline P7 & $0,0 \quad \mathrm{e}$ & $0,0 \quad \mathrm{~d}$ & $0,0 \quad \mathrm{c}$ & $0,0 \mathrm{~d}$ & $0,0 \mathrm{c}$ & $0,0 \quad \mathrm{~d}$ \\
\hline BNT $(0,05)$ & 0,6 & 3,0 & 0,7 & 1,1 & 3,0 & 2,0 \\
\hline
\end{tabular}

Keterangan : Angka-angka yang diikuti oleh huruf yang sama pada kolom yang sama menunjukan pengaruh yang tidak berbeda nyata pada taraf uji BNT 5\%. 
banyak, maka jumlah badan buah yang terbentuk juga banyak karena nutrisi yang terdapat dalam media tanam tersebar pada tiap primordia yang membentuk badan buah (Ningsih, 2008).

Pengamatan diameter tudung buah dilakukan pada minggu ke 6-9 MSI. Dari hasil pengamatan diketahui bahwa perlakuan $\mathrm{P}_{5}$ menghasilkan diameter tudung buah terbesar $14,7 \mathrm{~cm}$ dan tidak berbeda dengan diameter tudung buah pada perlakuan $\mathrm{P}_{0}-\mathrm{P}_{4}$ karena pada penelitian ini menggunakan bahan tanam yang sama yaitu satu varietas jamur. Hal ini sejalan dengan pernyataan Hariadi, dkk. (2013), bahwa salah satu faktor utama yang menyebabkan tidak adanya perbedaan diameter buah yang dihasilkan pada setiap perlakuan adalah dikarenakan faktor genetik yang sama yang berasal dari satu varietas jamur.

Produktivitas jamur juga dapat dilihatdari parameter bobot basat tubuh buah jamur. Pengamatan bobot basah jamur dilakukan pada minggu ke 6-9 MSI. Berdasarkan hasil penelitian diketahui bahwa perlakuan $\mathrm{P}_{0}$ menghasilkan bobot basah tubuh buah jamur terberat yaitu 9,1 gram dibandingkan dengan perlakuan lainnya. Bobot basah tubuh buah jamur dipengaruhi oleh pertumbuhan miselium. Hal ini sejalan dengan pernyataan Subowo dan Nurhasanah (2000) bahwa produksi jamur dapat dilihat dari pertumbuhan miseliumnya.

\section{KESIMPULAN}

Pertumbuhan dan produktivitas jamur tiram putih dipengaruhi oleh komposisi media tanam. Perlakuan media tanam $\mathrm{P}_{0}$ (Serbuk kayu sengon 100\%) memberikan hasil terbaik dibandingkan dengan perlakuan lainnya.

\section{DAFTAR PUSTAKA}

Amelia, F. J., K. Ferdinand, M.G. Maria, Waluyan, dan I.J. Sari. 2017. Pengaruh Suhu dan Intensitas Cahaya Terhadap Pertumbuhan Jamur Tiram di Tangerang. Jurnal Ilmiah Biologi (Biogenesis) 5(1): 1-6.

Cahyana, Y.A., Muchrodji, dan M. Bakrun. 2006. Jamur Tiram Pembibitan Pembudidayaan dan Analisis Usaha. Penebar Swadaya. Jakarta.

Dundar, A., H. Acay, and A. Yildiz . 2008. Yield Performances And Nutritional Contents Of Three Oyster Mushroom Species Cultivated On Wheat Stalk. African Journal of Biotechnology (7):3497-3501.

Hariadi, N., L. Setyobudi, dan E. Nihayati. 2013. Studi Pertumbuhan Dan Hasil Produksi Jamur Tiram Putih (Pleurotus ostreatus) Pada Media Tumbuh Jerami Padi Dan Serbuk Gergaji. Jurnal Produksi Tanaman 1(1): 47-53

Ningsih, L. 2008. Pengaruh jenis media tanam dan konsentrasi terhadap pertumbuhan dan produksi jamur tiram merah (Pleurotus flabellatus). Skripsi: 63-86. UIN. Malang.

Rahma A. R. dan A. S. Purnomo. 2016. Pengaruh campuran ampas tebu dan sabut kelapa sebagai media pertumbuhan alternatif terhadap kandungan jamur tiram (Pleurotus ostreatus). Jurnal Sains dan Seni ITS 5(2) :90-92

Subowo, Y.B. dan Nurhasanah. 2000. Produksi Jamur Kuping (Auricularia polytrica) Menggunakan Berbagai Media dan Umur Bibit. Jurnal Biologi Indonesia (2): 44-48. 
Sunanto, H. 2000. Budidaya Jamur Tiram, Edisi 1. CV. Aneka Ilmu ,Anggota IKAPI. Semarang.

Steviani, S. 2011. Pengaruh Penambahan Molase dalam berbagai Media pada Jamur Tiram (Pleurotus ostreatus). Skripsi 19-48. Universitas Sebelas Maret Surabaya.

Sumiati, E., E. Suryaningsih, dan Puspitasari. 2005. Perbaikan Jamur Tiram Putih (Pleurotus ostreatus) Strain Florida dengan Modifikasi Bahan Baku Utama Substrat. J. Hort 16(2): 96-17
Wiardani. 2010. Budidaya Jamur Konsumsi. Lily publisher. Yogyakarta

Widyastuti, N. dan S. Istini. 2004. Optimasi Proses Pengeringan Tepung Jamur Tiram Putih (Pleurotus ostreatus). Jurnal Ilmu Kefarmasian Indonesia 2 (1) : 1-4 